\title{
Identification of financial ratios applicable in the construction of a prediction model for bankruptcy of wood industry enterprises
}

\author{
Krzysztof Adamowicz $\bowtie$, Tomasz Noga \\ Poznan University of Life Sciences, Faculty of Forestry, Wojska Polskiego 28, 60-637 Poznań, Poland, \\ phone: 48 618487686, fax: 48 618487685, email: adamowic@up.poznan.pl
}

\begin{abstract}
At present, many early warning systems (EWS) are available. Most EWSs have been constructed based on data coming from various branches of economy. As a result, the effectiveness of these models in specific sectors of the national economy is frequently insufficient. There are no models dedicated to a specific branch, particularly the wood industry. Based on the Polish homogenous financial data supplied by the wood industry, it was decided to identify respective indexes, which may be used to construct a sector prediction model for bankruptcy in the wood industry. This study presents an analysis of indexes applied in 10 most popular EWSs used in Poland. In the course of the research process, a total of 5 financial ratios (FRs) were selected as best fitting to the investigated branch of economy. These included: profit from sales/balance sheet total, total income/mean annual total assets, operating costs/current liabilities, (operating profit - depreciation)/sales of products and equity capital/total debt.
\end{abstract}

\section{KeY WORDS}

early warning systems, prediction, financial risks, bankruptcy, financial ratios

\section{INTRODUCTION}

In recent years, the number of reported bankruptcies of enterprises has been increasing dramatically both on the national and global scale. Losses connected with bankruptcies of enterprises are estimated to amount to billions of dollars annually.

Numerical values of the so-called warning threshold, indicating a potential financial threat (bankruptcy), which may lead to the closure of enterprises, may be defined using early warning systems (EWS). An EWS is a system used to predict the success level, probable anomalies and to reduce the risk of crisis for transactions, systems, phenomena, companies and people. Furthermore, their current situations and probable risks may be identified quantitatively (Ozgulbas and Koyuncugil 2010). A financial EWS is a monitoring and reporting system that gives a signal on the probability of problems, risks and opportunities before they affect financial statements of companies. EWSs are used to detect financial performance, financial risk and potential bankruptcies. EWSs facilitate management decisions indicating opportunities to avoid or mitigate potential problems. Although ( $\mathrm{Li}$ and Wang, 2014) claimed that in the predic- 
tion of bankruptcy, non-financial elements are crucial, still practically all financial EWSs are based on financial statements. Balance sheets and income tables are the data sources that reflect the financial truth for early warning systems. In essence, the early warning system is a financial analysis technique, which identifies the achievement analysis of an enterprise in view of its industry with the help of financial ratios (Koyuncugil and Ozgulbas 2012). Most papers published to date on the construction of EWS models are based on an adequate selection of financial ratios (e.g., Adamowicz and Noga 2017; Abumustafa 2006; Altman et al. 1968; Altman et al. 1977; Barniv and Hathorn 1997; Barniv and McDonald 1992; Beaver 1966; Berg et al. 2004; Bredart 2014; Brockett and Cooper 1990; Brockett et al. 2006; Chen 2014; Davis and Karim 2008; Deakin 1972; Edison 2003; El-Shazly 2003; Katz 2006; Koyuncugil and Ozgulbas 2007, 2008, 2009a, 2009b; Kyong et al. 2006; Laitinen and Chong 1999; Lee and Urrutia 1996; Lestano et al. 2004; Lin et al. 2010, 2012; Noga et. al. 2014; Pantalone and Platt 1987; Salas and Saurina 2002; Taffler and Tisshaw 1977; Trieschmann and Pinches 1973; Wu 2007; Yang et al. 2001; Zavgren 1985; Zmijewski 1984). In general, financial ratios (FRs), recognized as one of the most important factors affecting bankruptcy prediction, are used to develop prediction models (Altman 1968; Beaver 1966; Liang et al. 2016). A synthetic overview of the contribution of individual authors to the construction of various prediction models for financial changes was presented, for example, by Koyuncugil and Ozgulbas (2012), Balcaen and Ooghe (2006) and Liang et al. (2016).

Establishment of an effective early warning system may help the company operators make relevant decisions as soon as possible when finding a crisis, improve the operating results and the financial condition of the enterprise, while it may also make investors avoid or reduce investment losses (Xu et al. 2015). However, to achieve this, adequate methods to predict bankruptcy of enterprises are required. While several methods forecasting financial changes are currently available, most of them pertain to a general economic situation. At present, a significant problem is connected with a lack of prognostic models for most branches of the economy, constructed on a homogeneous experimental group (Adamowicz and Noga 2014). It is necessary to estimate models developed on similar homogeneous populations, which may potentially enhance the discriminatory power of a function, and thus, also that of prediction. This thesis was supported by Prusak (2012) and Tymoszczuk (2013), who stressed the importance of construction of sector models. Additionally, Dąbrowski and Boratyńska (2011) indicated the need to construct models for a limited group of entrepreneurs, so that they are no longer applied indiscriminately to any type of production. We need to stress here that at present, attempts are being made to create methodological foundations for the prediction of economic changes in terms of individual sectors. For example, Platt and Platt (2002) conducted a research on the American car industry indicating the need for the construction and verification of forecasts prepared using models based on a uniform experimental sample. The thesis on the justification for the sector character of the models and their effectiveness was confirmed by the studies by Wędzki (2005), who stated that a model estimated on a national single sector sample provides forecasts better by several percentage points than those standardised for many sectors. It is generally accepted that general companies' characteristics concerning industry type and companies' size have also proven to be very important variables in failure prediction (Bilderbeek 1978; Daubie and Meskens 2002; Hill et al. 1996; Laitinen 1992; Mensah 1984; Taffler 1984; Ooghe et al. 2003). At present, we have no model that would be constructed solely based on a sector experimental sample coming from the wood industry (Adamowicz and Noga 2014). For this reason, it was decided to construct a wood industry prediction model for bankruptcy (WIPMB). The first step in the formulation of a specific discrimination equation is to identify FRs applicable in its construction.

Selection of the time interval for the study was determined by the economic changes taking place in Poland and the availability of research material.

\section{THE AIM AND SCOPE OF THE STUDY}

As it was reported by (Koyuncugil and Ozgulbas 2012), the steps of the EWS include: Step 1 - Preparation of data collection; Step 2 - Implementation of the DM method; Step 3- Determination of risk profiles; Step 4 - Identification of the current situation of SMEs in terms of risk profiles and early warning signs; and Step 5 - Description of roadmaps for SMEs.

The primary aim of this study was to realise the first step in the construction of an EWS for the wood in- 
dustry. Based on homogeneous financial data provided by the wood sector, it was decided to identify respective indexes, which will be used to construct a sector EWS for Polish wood industry enterprises.

The primary research problems included a review of potentially available financial information from wood industry enterprises as well as a review and selection of FRs applied in the prediction models most commonly used in Poland taking into consideration their adaptation to the analysed sector.

The scope of analyses in this study covered seven consecutive years.

\section{Methods}

In order to identify FRs for the construction of the WIPMB for Polish wood industry enterprises, several EWSs applied in Poland were conducted. Based on literature reports, ten most efficient bankruptcy prediction methods were selected. Next, applying the selected methods of multivariate discrimination analysis, forecasts of financial situations were prepared for the analysed companies. Forecasts were based on past economic events. This made it possible to verify the obtained results with the actual financial situation of the analysed enterprises. Forecasts were based on selected discrimination models using prognostic properties of FRs. Forecasts were based on the reporting data collected from the Polish wood industry enterprises.

Enterprises, on which the source financial materials were collected, were divided and selected using the Polish Classification of Economic Activity 2007 (PKD). In the research process, we used data coming from the enterprises operating solely in the area where timber has been the basis for the production process. These enterprises were classified to the sections (Ordinance of 24.12.2007): 16 - Production of wood products; 17 - Production of paper and paper products, and 31 - Production of furniture.

\section{Research material}

The primary criterion, which was included when accumulating source data, was connected with the reliability of financial information. We took into consideration the opinion by Gruszczyński (2005) that a key element in the prediction of bankruptcy is to select the research sample. Prior to empirical analysis, the source data were collected and catalogued in order to create a comprehensive, reliable and cohesive database of financial data for individual wood companies. We identified and catalogued wood companies, for which a motion for bankruptcy and/or a motion for the initiation of debt conciliation were filed and identified the enterprises with a stable financial situation. Following the recommendation of Hołda (2001), only those enterprises publishing complete financial reports were selected for the estimation of parametric models.

Financial reports of enterprises came from Regional Courts and credit information agencies. For all enterprises in the analytical sample, data were collected; based on this data, their financial-economic situation may be characterised. The primary criterion characterising a given enterprise as bankrupt was the submission of a bankruptcy motion to a respective regional Economic Department of the Regional Court. Wood enterprises with an advantageous economic and financial situation were selected based on general financial information contained in balance sheets as well as profit and loss accounts, in which the focus was on total debt, profitability and liquidity indexes.

Collected source materials were complete and selected in terms of the organisational structure, taking into account the volume of financial assets of analysed enterprises. The sample of non-bankrupt enterprises comprised only those companies that did not go bankrupt during the period of analysis.

Enterprises for which the financial data were used in this study came from various regions of Poland and represented diverse legal forms of economic activity. They included stock corporations, limited liability companies and cooperatives publishing financial statements.

Collected data were analysed in order to verify whether the data had a normal distribution. As a result, the investigated sample comprised a total of 83 companies, which declared their bankruptcy in the years 2006-2012, as well as 52 enterprises, which in the same period continued their economic activity.

\section{Selection of financial ratios (FRs)}

In order to select respective explanatory variables for the construction of WIPMB, all FRs applied in the analysed models were verified. The training set used aver- 
aged (3-year) FRs out of the proposed 10 EWSs. Out of the 135 enterprises, a balanced training set was prepared $(\mathrm{N}=72)$, a balanced verification set $1(\mathrm{~N}=30)$ and a non-balanced verification test $2(\mathrm{~N}=33$ "problem" enterprises).

Financial ratios for the construction of WIPMB were selected based on trait clustering using aggregation of centres of gravity and Pearson's measures of distance 1-r, and a hierarchical graph was prepared. Based on this graph, groups of variables were identified. In the next steps, the coefficients of determination $\mathrm{R}^{2}$ were established between the preselected explanatory variables (FRs) and the explained variables. The last element of an appropriate selection of FRs applicable in the development of WIPMB was to verify the preselected explanatory variables in terms of their similarities. In order to eliminate doubled explanatory variables, we applied the progressing stepwise regression. We selected those FRs that exhibited a level of significance below 0.10 . Statistical analysis of the results was conducted using the STATISTICA 10 PL package and EXCEL 2013.

\section{Results}

\section{FRs applied in Polish EWSs}

The most popular EWSs to assess the financial situation of Polish enterprises include models developed by Altman, Gajdek and Stos, Hadasik, Hołda, Jagiełło, Mączyńska, the Poznań model, as well as the Prusak 1, Prusak 2 and Wierzba models.

Professor Altman developed many prediction models for bankruptcy. His best known EWS was created in 1968 (Altman, 1968). It was designed for the listed companies (Divišová, 2013). This model was repeatedly modified. At present, in the most commonly used modified Altman's model (ALTMAN), the prediction of bankruptcy for industrial enterprises is most frequently based on five indexes (Divišová 2013): X_1 - working capital/total assets, X_2 - retained profit/total assets, X_3 - EBIT/total assets, X_4 - Equity capital/total debt and X_5 - Income from sales/total assets.

Another interesting example of Polish attempts to search for an effective early warning model for bankruptcy is provided by the discrimination analysis by J. Gajdek and D. Stos, developed based on FRs of 40 enterprises (Godlewska 2010). Prediction of enterprise bankruptcy using their model (GAJDKA I STOS) is based on five financial ratios: X_1 - income from sales/ total assets, X_2 - (current liabilities x 360)/manufacturing costs of sold production, X_3 - net profit/averaged annual value total assets, $\mathrm{X} \_4$ - gross profit/net income from sales and X_5 - total liabilities/total assets.

In the model by Hadasik (HADASIK), the prediction is based on six financial ratios (Hadasik 1998): X_1 - current assets/current liabilities, X_2 - (current assets - stock)/current liabilities, X_3 - total liabilities/total assets, X_4 - (current assets - current liabilities)/total liabilities, X_5-amounts receivable/income from sales and X_6 - stock/income from sales.

The early warning system by A. Hołda (HOŁDA) was developed based on an analysis of the financial reports of eighty enterprises operating in Poland in the years 1993-1996. Half of them, in the opinion of the author, did not face the risk of bankruptcy, while bankruptcy proceedings were conducted for the other forty. Initially, the analysis involved an establishment of twenty-eight financial ratios calculated based on balances and profit and loss accounts. In the final stage of the research, for a discrimination function, the selection was limited to five indexes, describing the area of liquidity, profitability, debt and efficiency of enterprises (Godlewska 2010; Hołda 2001; Wojnar 2014): X_1 - current assets/current liabilities, X_2 - total liabilities x 100/total assets, X_3 - Total receipts/averaged annual (average) total assets, X_4 - net profit (loss) x 100/average total assets and $X \_-5$ - average current liabilities $\mathrm{X}$ $360 /$ cost of sold products, goods and materials.

The Przemysł NBP model (JAGIEŁŁO) is the latest model of all those selected for this study (Jagiełło 2013). It was constructed based on the financial results of 80 enterprises in 2008. Among them, 50\% were bankrupt, while the other half were entities not threatened with bankruptcy (Firlej et al. 2014). In this model, prediction is based on three financial ratios: $X_{-} 1$ - gross sales/operating costs, $X \_2$ - total receipts/total assets and X_3 - equity capital/total liabilities.

The model developed by Mączyńska (MACZYNSSKA) was constructed in 1994 as a reaction to the need for an adaptation of the Western Altman model to the Polish conditions. In the model proposed by Mączyńska, prediction is based on six financial ratios (Mączyńska and Zawadzki 2006; Wardzińska 2012): X_1 - gross profit + depreciation/total liabilities - debt 
paying ability, X_2 - balance sheet total/total liabilities - total debt ratio, X_3 - gross profit/balance sheet total - profitability of assets, $X \_4-$ Gross profit/income from sales, X_5 - stock/income from sales and X_6 - income from sales/balance sheet total. The concept proposed by Mączyńska (1994), based on an adaptation of the Jacobs function, proved to be a very good example of the bankruptcy model, characterised by a high prognostic value under the Polish economic conditions.

Another EWS is the Poznań model (POZNAŃSKI) was created based on the financial results of 100 enterprises. Half of them were enterprises in excellent condition, while the other half were bankrupt enterprises. Financial results, which were used by its creators, covered the period from 1999 to 2002 (Firlej et al. 2014). In this model, the prediction is made based on four financial ratios: $X \_1-$ net financial results/total assets, X_2 - (current assets - stock)/current liabilities, X_3 - fixed capital/total assets and X_4 - financial results from sales/income from sales.

Prusak (2004) developed two models - one with a forecast for one following year (PRUSAK1) with four financial indexes, and the other (PRUSAK2) with a forecast for two successive years (with three financial indexes) in relation to the period, in which companies were declared bankrupt. In the first formula, the following FRs were used: X_1 - profit operating/balance sheet total, X_2 - operating costs/current liabilities, X_3 - current assets/current liabilities and X_4 - profit operating/income from sales. In the other model, three financial ratios were applied: X_1 - (net results + depreciation)/total liabilities, X_2 - operating costs/mean short-term liabilities and X_3 - profit from sales/balance sheet total.

The model developed by Wierzba (WIERZBA) was created based on the financial results of 48 enterprises, including 24 in good condition and 24 on the verge of bankruptcy (Wierzba 2000). This model was estimated based on the financial results, which the selected enterprises reported in the years 1995-1998. The author selected 4 from among the set of 12 preselected indexes, which were used to construct a linear discrimination function (Kisielinska and Waszkowski 2010): X_1 - (operating profit - depreciation)/total assets, X_2 - (operating profit - depreciation)/sales products, X_3 - current assets/total liabilities and X_4 - working capital/total assets.

\section{Reduction of explanatory variables}

In the next stage of analyses, the number of explanatory variables was reduced. Based on clustering of characteristics, a hierarchic graph was prepared using the aggregation of centres of gravity and Pearson's 1-r distance. Based on this graph, groups of variables were identified. The following 15 FRs were selected for further analyses: Prusak 2_X3, Hołda_X3, Prusak 1_X2, Hadasik_X5, Gajdka i Stos_X2, Hołda_X2, Hadasik_X6, Hadasik_X4, Wierzba_X3, Wierzba_X2, Hołda_X1, Altman_X4, Prusak 1_X1, Hołda_X5 and Prusak 2_X1.

Indexes were selected using the progressing stepwise regression. These indexes were characterised by the greatest predictive properties for the analysed group of enterprises as well as the empirical level of significance $[p]$ lower than 0.10 . (Tab. 1).

Table 1. Results of progressing stepwise regression of explanatory variables characteristic of wood industry enterprises (balanced training set: $\mathrm{N}=72$ )

\begin{tabular}{|l|c|c|c|c|c|}
\hline $\begin{array}{c}\text { Explanatory } \\
\text { variables }\end{array}$ & $\begin{array}{c}\text { Wilks } \\
\text { lambda }\end{array}$ & $\begin{array}{c}\text { Particle } \\
\text { Wilks }\end{array}$ & $\mathrm{F}$ & $\mathrm{p}$ & $\begin{array}{c}\text { Lati- } \\
\text { tude }\end{array}$ \\
\hline PRUSAK2_X3 & 0,83 & 0,70 & 27,75 & 0,000 & 0,80 \\
\hline HOŁDA_X3 & 0,68 & 0,86 & 11,07 & 0,001 & 0,75 \\
\hline ALTMAN_X4 & 0,63 & 0,93 & 4,96 & 0,029 & 0,60 \\
\hline WIERZBA_X2 & 0,61 & 0,95 & 3,25 & 0,076 & 0,93 \\
\hline PRUSAK1_X2 & 0,61 & 0,96 & 2,99 & 0,089 & 0,59 \\
\hline
\end{tabular}

\section{Discussion}

Bankruptcy induces substantial costs to the business community such as court costs, legal assistance costs, lost sales, lost profits, higher costs of credits, inability to issue new securities, and lost investment opportunities (e.g., Bris et al. 2006; Davydenko et al. 2012; Elkamhi et al. 2012) - for a detailed review on the costs of bankruptcy, we refer the reader to Branch (2002). Therefore, the design of reliable models to predict bankruptcy is crucial to audit business risks and assist managers in preventing business failure, and to assist stakeholders in the assessment and selection of companies to collaborate with or invest in (e.g., Ahn et al. 2000; Balcaen and Ooghe 2006).

In recent years, we have been additionally observing an increased number of corporate bankrupt- 
cies. This problem concerned both manufacturing and trade enterprises (Grzegorzewska 2008; Nehrebecka and Dzik 2012). In recent years, the importance of timber trade has been increasing. The developing wood industry requires continuous supply of a growing volume of timber in order to satisfy current market demand. It needs to be stressed that the supply of round wood depends not only on economic factors, but also on the volume and structure of forest resources in a given country and the adopted legal regulations (Adamowicz 2010; Adamowicz et al. 2016). The effect of non-economic factors increases the threat of bankruptcy for timber conversion companies. This provides justification for the decision to undertake this research concerning the development of possibly the most reliable bankruptcy prediction method for wood sector companies.

In the course of this research project presented in this paper, the currently existing corporate bankruptcy models were taken into consideration. Studies concerning applied general economic models in the evaluation of the situation in the wood sector (Adamowicz and Noga 2014; Noga et. al. 2014) show that their efficiency is insufficient. It needs to be stressed that the proper application of EWSs may be an important element in the decision-making support. At the same time, an inadequate selection of an appropriate forecasting method may contribute to erroneous decisions. This opinion is shared by Dąbrowski and Boratyńska (2011), who claimed that the results of forecasts provided by different EWSs are inconsistent.

We need to agree with Kocel (2010) that predictions should be as accurate as possible, particularly in view of the potential financial losses incurred in the case of erroneous forecasts. Having the above in mind, it was attempted to develop an innovative single sector bankruptcy prediction model for timber conversion enterprises. It was assumed that the sector model (WIPMB) should exhibit a greater effectiveness of forecasts in comparison to the forecasts provided by the currently known theoretical models. The first step in the construction of such a model is connected with the appropriate selection of FRs. For this reason, the FRs used in 10 most common EWSs applied in Poland were analysed in this study. Forecasts were prepared and the next FRs suitable for the construction of WIPMB were identified.
In view of studies presented by Koyuncugil and Ozgulbas (2012), who used data from almost 8 thousand small and medium-sized Turkish enterprises, certain objections may be voiced concerning the number of companies used in this study. When identifying FRs best fit for the construction of WIMBP, the financial data from 135 timber conversion enterprises were used, while in the balanced training set, it was 74 companies. However, they were homogeneous data and not - as in the case of studies presented by Koyuncugil and Ozgulbas (2012) - data concerning small and medium sized companies from different sectors of the national economy. Obtained source materials were complete and selected in terms of their organisation structure, including the volume of financial assets of the analysed enterprises. Moreover, it needs to be stressed that studies on EWSs with no indication of a specific sector in many cases were also conducted on a smaller experimental sample (e.g., Jagiełło 2013; Wierzba 2000).

In this study, a total of 15 indexes were used, exhibiting considerable predictive properties in the wood sector. Next, their number was reduced. The reduction of the number of variables was necessary, since many indexes applied in the analysed multiple sector models are correlated at the significance level close to one. Application of completely redundant variables in one model would result in an incorrect matrix conditions, thus preventing estimation of discrimination function coefficients (Stanisz 2007). In order to address this problem, clustering of characteristics was conducted using the hierarchical method applying aggregation of centres of gravity and Pearson's 1-r distance measure. In the clustering of characteristics using cluster analysis, Pearson's 1-r value was used as a measure of distance. Initially, it was attempted to specify appropriate indexes using linear regression. It was a preliminary analysis, which is typically conducted before the transition to the modelling stage in order to predetermine which variables have a predictive value. In this study, we conducted simple tests for two-dimensional relationships, that is, index-financial situation. As a result of these analyses, we stated that 7 indexes have predictive value. A drawback of this approach is the fact that the analyses conducted in this study did not take into consideration the mutual correlation of indexes. For this reason, eventually, it was decided not to use this 
approach and apply discriminatory analysis. Similarly, as other multivariate techniques, discriminatory analysis, next to the relationship of indexes with a dependent variable, also considers mutual correlations of indexes. Generally, the stronger the indexes are correlated with one another, the more the results of simple tests will differ from those multivariate tests. Among the 15 FRs analysed in this study, we also investigated such pairs of indexes, which were greatly correlated with one another (e.g., 0.87). Thus, modelling provided us with models having structures that differed considerably from what could be expected based on the results of simple analyses. Therefore, among the 15 FRs, only 5 were selected, which in the opinion of the authors are suitable for the construction of WIPMB.

At present, studies are being continued on the construction WIPMB. In further stages of the research, the importance of individual indexes needs to be specified. This will be provided using canonical analysis. As a result, a new EWS will be constructed based on the FRs most accurately characterising the wood sector.

We must agree with the opinion of Balcaen and Ooghe (2006) that failure prediction models based on financial ratios implicitly assume that all relevant failure or success indicators - both internal and external - are reflected in the annual accounts. However, it is clear that not all relevant information is reflected in the annual accounts. In this context, Argenti (1976) stated that 'while these [financial] ratios may show that there is something wrong ... I doubt whether one would dare to predict collapse or failure on the evidence of these ratios alone' (p. 138). In addition, Zavgren (1985) pointed out that 'any econometric model containing only financial statement information will not predict with certainty the failure or nonfailure of a company' (p. 22-23). Furthermore, Maltz et al. (2003) mentioned that the use of financial measures as sole indicators of organisational performance is limited. For this reason, some authors have advised including non-accounting or qualitative failure indicators in failure prediction models (Becchetti and Sierra 2003; Daubie and Meskens 2002; Doumpos and Zopoudinis 1999; Keasey and Watson 1987; Lehmann 2003; Lussier 1995; Lussier and Corman 1994; Ohlson 1980; Sheppard 1994; Slowinski and Zopudinis 1995).

In the literature on the subject, in addition to financial ratios (FRs), corporate governance indicators
(CGIs) have been found to be another important type of input variable. However, this will not change the fact that the first step in the construction of EWS is to develop an empirical formula making it possible to preliminarily adopt future scenarios. In general, the input variables (or features) such as financial ratios and prediction techniques (e.g., statistical and machine learning techniques) are the two most important factors affecting the prediction performance. The next step will be to search for non-financial factors affecting efficiency of forecasts. This may be evidenced by the results of studies presented by (Liang et al. 2016), who stated that the most important features for effective bankruptcy prediction include the FR categories of solvency and profitability and the CGI categories of board structure and ownership structure.

\section{Conclusion}

Based on the conducted investigations, a total of 15 FRs were selected constituting the explanatory variables best fitting EWSs for wood sector companies. These included PRUSAK 2_X3, HOŁDA_X3, PRUSAK 1_X2, HADASIK_X5, GAJDKA I STOS_X2, HOŁDA_X2, HADASIK_X6, HADASIK_X4, WIERZBA_X3, WIERZBA_X2, HOŁDA_X1, ALTMAN_X4, PRUSAK 1_X1, HOŁDA_X5 and PRUSAK 2_X1.

Among these $15 \mathrm{FRs}$, using the progressing stepwise regression method, indexes were selected that exhibited the empirical significance level $[p]$ lower than 0.10 . Thus, it was stated that the most suitable FRs for the construction of a single sector EWS dedicated for the wood industry are FRs: PRUSAK2_X3, HOŁDA_X3, ALTMAN_X4, WIERZBA_X2 and PRUSAK1_X2.

Presented studies are a preliminary step for the construction of WIPMB. Identification of FRs will facilitate the construction of a new sector EWS model. At present, further investigations are being conducted in this respect. The next step will consist of the evaluation of the discriminatory power of the estimated function. For this purpose, it is necessary to perform canonical analysis and develop the so-called rough coefficients of the discriminatory function. Based on these coefficients, the equation for the WIPMB discriminatory function will be formulated. 


\section{References}

Abumustafa, N.I. 2006. Development of an early warning model for currency crises in emerging economies: An empirical study among Middle Eastern countries. International Journal of Management, 23 (3), 403-411. http://search.proquest.com/open view/3c1199229c95d431c9308af57c319e2a/1?pqorigsite $=$ gscholar

Adamowicz, K. 2010. Price elasticity of demand for timber on primary local wood market in Poland. Sylwan, 154 (2), 130-138. http://sylwan.ibles.waw. $\mathrm{pl} / \mathrm{pls} / \mathrm{apex} / \mathrm{f}$ ? $\mathrm{p}=105: 10: 248927025306901:: \mathrm{NO}$ : :P10_NAZWA_PLIKU,P10_ARTYKUL:F1164236 155\%2F2010_02_130au.pdf\%2C2009018

Adamowicz, K., Noga, T. 2014. Multivariate analysis of bankruptcy in companies in the wood sector. Sylwan, 158 (9), 643-650. http://sylwan.ibles.waw.pl/ pls/apex/f?p=105:10:248927025306901::NO::P10 NAZWA_PLIKU,P10_ARTYKUL:F2046347597 \%2F2014_09_643au.pdf\%2C2014003

Adamowicz, K., Noga, T. 2017. Assessment applicability of selected models of multiple discriminant analyses to forecast financial situation of Polish wood sector enterprises. Folia Forestalia Polonica, Series A - Forestry, 59 (1), 59-67. https:// depot.ceon.pl/bitstream/handle/123456789/11697/ Journal_10340-Volume59_1-06article_ffp-59-6. pdf? sequence $=1$.

Adamowicz, K., Szramka, H., Starosta-Grala, M., Szczypa, P. 2016. Export and import of timber in selected member states of the European Union. Sylwan, 160 (3), 179-186. http://sylwan.ibles.waw. $\mathrm{pl} / \mathrm{pls} / \mathrm{apex} / \mathrm{f}$ ? $\mathrm{p}=105: 10: 248927025306901: \mathrm{NO}$ : :P10_NAZWA_PLIKU,P10_ARTYKUL:swiezy_ plik\%2C2015093.

Ahn, B.S., Cho, S.S., Kim, C.Y. 2000. The integrated methodology of rough set theory and artificial neural network for business failure prediction. Expert Systems with Applications, 18 (2), 65-74. DOI: 10,1016 / S0957-4174 (99) 00053-6.

Altman, E.I. 1968. Financial ratios, discriminant analysis and the prediction of corporate bankruptcy. Journal of Finance, September, 589-609. DOI: 10.1111/j.1540-6261.1968.tb00843.x.

Altman, E.I., Haldeman, G., Narayanan, P. 1977. Zeta analysis: A new model to identify bankruptcy risk of corporations. Journal of Banking and Finance, June, 29-54. DOI:10.1016/0378-4266(77)90017-6.

Argenti, J. 1976. Corporate Collapse: The Causes and Symptoms. Mc Graw-Hill, London.

Balcaen, S., Ooghe, H. 2006. 35 years of studies on business failure: An overview of the classic statistical methodologies and their related problems. The British Accounting Review, 38 (1), 63-93. DOI: 10.1016/j.bar.2005.09.001

Barniv, R., Hathorn, J. 1997. The merger or insolvency alternative in the insurance industry. Journal of Risk and Insurance, 64 (1), 89-113. DOI: 10.2307/253913.

Barniv, R., McDonald, J.B. 1992. Identifying financial distress in the insurance industry: A synthesis of methodological and empirical issues. Journal of Risk and Insurance, 59, 543-573. DOI: $10.2307 / 253344$.

Beaver, W. 1966. Financial ratios as predictors of failure. Journal of Accounting Research, 4, 71-111. DOI: $10.2307 / 2490171$.

Becchetti, L., Sierra, J. 2003. Bankruptcy risk and productive efficiency in manufacturing firms. Journal of Banking \& Finance, 27 (11), 2099-2120. DOI:10.1016/S0378-4266(02)00319-9.

Berg, A., Borensztein, E., Pattillo, C. 2004. Assessing early warning systems: How have they worked in practice? IMF Working Paper, March 2004. Retrieved April 2009. http://citeseerx.ist.psu.edu/ viewdoc/download?doi=10.1.1.494.2583\&rep=rep1 \&type $=$ pdf.

Bilderbeek, J. 1978. Het voorspellen van falingen. Financiele kengetallen als thermometer voor de ondernemingsdoorlichting. Economisch en Sociaal Tijdschrift, 32 (1), 5-25.

Branch, B. 2002. The costs of bankruptcy: A review. International Review of Financial Analysis, 11 (1), 39-57. http://citeseerx.ist.psu.edu/viewdoc/downlo ad?doi $=10.1 .1 .463 .5060 \&$ rep $=$ rep1\&type $=$ pdf.

Bredart, X. 2014. Financial distress and corporate governance: Theimpact of board configuration.International Business Research, 7 (3), 72-80. https://scholar.google.pl/scholar?q=Bredart $\% 2 \mathrm{C}+\mathrm{X} .+\% 282014 \% 29 .+\mathrm{Fi}$ nancial + distress + and + corporate + governance $\% 3 \mathrm{~A}+$ The+impact + of + board + configura-tion. + Internation al+Business+Research $\% 2 \mathrm{C}+7+\% 283 \% 29 \% 2 \mathrm{C}+72-$ $80 \& b t n G=\& h l=p l \& a s \_s d t=0 \% 2 C 5$. 
Bris, A., Welch, I., Zhu, N. 2006. The Costs of Bankruptcy: Chapter 7 liquidation versus chapter 11 reorganization. Journal of Finance, 61 (3), 1253-1303. http://citeseerx.ist.psu.edu/viewdoc/download?doi= 10.1.1.365.4931\&rep=rep1\&type $=$ pdf

Brockett, P.L., Cooper, W.W. 1990. Report to the State Auditor and the State Board of Insurance on Early Warning Systems to Monitor the Performance of Insurance Companies in Texas. Office of the State Auditor, Austin, TX.

Brockett, P.L., Golden, L.L., Jang, J., Yang, C. 2006. A comparison of neural network, statistical methods and variable. Journal of Risk and Insurance, 73 (3), 397-419. https://www.researchgate.net/profile/Patrick_Brockett/publication/23690716_A_Comparison_of_Neural_Network_Statistical_Methods_and_Variable_ Choice_for_Life_Insurers'_Financial_Distress_Prediction/links/02e7e518c174b1972a000000.pdf

Chen, I.J. 2014. Financial crisis and the dynamics of corporate governance: Evidence from Taiwan's listed firms. International Review of Economics \& Finance, 32, 3-28. DOI:10.1016/j.iref.2014.01.004

Daubie, M., Meskens, N. 2002. Business failure prediction: a review and analysis of the literature. Working Paper, Department of Productions and Operations Management, Catholic University of Mons, Belgium, 1-15. http://link.springer.com/ chapter/10.1007/978-3-642-57478-8_5\#page-1

Davis, E.P., Karim, D. 2008a. Comparing early warning systems for banking crises. Journal of Financial Stability, 4 (2), 89-120. DOI: 10.1016/j. jfs.2007.12.004

Davydenko, S.A., Strebulaev, I.A., Zhao, X. 2012. A market-based study of the cost of default. Review of Financial Studies, 25 (10), 2955-2999. http://rfs. oxfordjournals.org/content/25/10/2959

Dąbrowski, B.J., Boratyńska, K. 2011. Using discriminant analysis models for insolvency predictions on a case of stock market index WIG-Spożywczy companies. Zeszyty Naukowe $S G G W w$ Warszawie. Ekonomika i Organizacja Gospodarki Żywnościowej, 89, 163-173. http://www.wne.sggw. pl/czasopisma/pdf/EIOGZ_2011_nr89_s163.pdf

Deakin, E.B. 1972. A discriminant analysis of predictors of business failure. Journal of Accounting Research, 10 (1), 167-179. http://www.jstor.org/ stable/2490225?seq=1\#page_scan_tab_contents
Divišová, P. 2013. The Use of Methods for Evaluation of Financial Health of Companies Operating in Chemical Industry. Crisis, 2 (3), 4.

http://www.wseas.us/e-library/conferences/2013/Chania/AEBDa/AEBDa-41.pdf

Doumpos, M., Zopoudinis, C. 1999. A multicriteria discrimination method for the prediction of financial distress: the case of Greece. Multinational Finance Journal, 3 (2), 71-101. http://www.mfsociety.org/ modules/modDashboard/uploadFiles/journals/MJ 644 p16stg5a3c17bbkm51a4m1gmkc5e4.pdf

Edison, H.J. 2003. Do indicators of financial crises work? An evaluation of an early warning system. International Journal of Finance and Economics, 8 (1), 11-53.

Elkamhi, R., Ericsson, J., Parsons, C.A. 2012. The cost and timing of financial distress. Journal of Financial Economics, 105 (1), 62-81. DOI: 10.1016/j.jfineco.2012.02.005

El-Shazly, A. 2003. Early warning of currency crises: An econometric analysis for Egypt. The Middle East Business and Economic Review, 18 (1), 34-48. http://search.proquest.com/openview/d1aa55f64ab9 b658bb9b99aec005b261/1?pq-origsite $=$ gscholar

Firlej, K., Bargieł, A., Szymański, M. 2014. The risk of failure of the food producing companies in Poland - on the example of companies listed on wig-food industry index. Folia Pomeranae Universitatis Technologiae Stetinensis, Oeconomica, 74 (1), 63-72. http://krzysztoffirlej.pl/nauka-i-organizacja/zagrozenie-upadloscia-przedsiebiorstw-przemyslu-spozywczego-w-polsce-na-przykladzie-spolek-z-indeksuwig-spozywczy/

Godlewska, S. 2010. The Effectiveness of Polish Bankruptcy Prediction Models in Identifying the Insolvent Threat of Incorporated Enterprises. Annales Universitatis Mariae Curie-Skłodowska. Sectio H, Oeconomia, 44, 701-714. http://bazekon.icm.edu. pl/bazekon/element/bwmeta1.element.ekon-element-000171257421

Gruszczyński, M. 2005. Strengths and Weaknesses of Bankruptcy Models. Materiaty i Prace Instytutu Funkcjonowania Gospodarki Narodowej, 93, 185-187. http://bazekon.icm.edu.pl/bazekon/element/bwmeta1.element.ekon-element-000171282751

Grzegorzewska, E. 2008. The bankruptcy of companies in Poland and other EU countries. Ekonomi- 
ka i Organizacja Gospodarki Żywnościowej, 68, 51-63. http://www.wne.sggw.pl/czasopisma/pdf/EIOGZ_2008_nr68.pdf\#page $=48$

Hadasik, D. 1998. Upadłość przedsiębiorstw w Polsce i metody jej prognozowania. Zeszyty Naukowe. Seria 2, Prace Habilitacyjne / Akademia Ekonomiczna w Poznaniu, 153, 1-198. http://bazekon.icm. edu.pl/bazekon/element/bwmeta1.element.ekonelement-000072854733

Hamrol, M., Czajka, B., Piechocki, M. 2004. Analiza dyskryminacyjna. Przegląd najważniejszych modeli. Przeglad Organizacji, 4, 34 -38. http:// yadda.icm.edu.pl/yadda/element/bwmeta1.element.ekon-element-000000120372?q=bwmeta1. element.ekon-element-f52cfc2e-6523-37ed-adb21738ca76a3f4; $\& \mathrm{qt}=$ CHILDREN-STATELESS

Hill, N.T., Perry, S.E., Andes, S. 1996. Evaluating firms in financial distress: An event history analysis. Journal of Applied Business Research, 12 (3), 60-71. http://cluteinstitute.com/ojs/index.php/JABR/article/ viewFile/5804/5886

Hołda, A. 2001. Prognozowanie bankructwa jednostki w warunkach gospodarki polskiej z wykorzystaniem funkcji dyskryminacyjnej ZH. Rachunkowość, 5, 306-310.

Jagiełło R. 2013. Analiza dyskryminacyjna i regresja logistyczna w procesie oceny zdolności kredytowej przedsiębiorstw. Materiały i Studia NBP, 286, 71-72.

Katz, M. 2006. Multivariable analysis: A practical guide for clinicians. New York: Churchill-Livingstone.

Keasey, K., Watson, R. 1987. Non-financial symptoms and the prediction of small company failure: a test of Argenti's hypotheses. Journal of Business Finance \& Accounting, 14 (3), 335-354.

Kisielińska, J., Waszkowski, A. 2010. The financial liquidity of agriculture farms situated in Lubelskie voivodeship. Zeszyty Naukowe Szkoty Głównej Gospodarstwa Wiejskiego, Ekonomika i Organizacja Gospodarki Żywnościowej, 82, 17-31. http:// www.wne.sggw.pl/czasopisma/pdf/EIOGZ_2010_ nr82.pdf\#page $=17$

Kocel J. 2010. Methodological foundations of financial and economic forecast for the State Forests National Forest Holding. Sylwan, 154 (1), 41-51. http://sylwan.ibles.waw.pl/pls/apex/f?p=105:10:0::NO::P10 NAZWA_PLIKU,P10_ARTYKUL:F546833311\%2 F2010_01_041au.pdf\%2C2009025
Koyuncugil, A.S., Ozgulbas, N. 2007. Developing financial early warning system via data mining. In: Proceedings Book of 4th Congress of SMEs and Productivity, Istanbul, 153-166.

Koyuncugil, A.S., Ozgulbas, N. 2008. Early warning system for SMEs as a financial risk detector. In: Data mining applications for empowering knowledge societies (ed.: Hakikur Rahman), Idea Group Inc., New York, 221-240.

Koyuncugil, A.S., Ozgulbas, N. 2009a. Measuring and hedging operational risk by data mining. In: Proceedings Book of World Summit on EconomicFinancial Crisis and International Business, Washington, $1-6$.

Koyuncugil, A.S., Ozgulbas, N. 2009b. An intelligent financial early warning system model based on data mining for SMEs. In: Proceedings of the International Conference on Future Computer and Communication, Kuala Lumpur, Malaysia, 662-666. DOI: 10.1109/ICFCC.2009.118

Koyuncugil, A.S., Ozgulbas, N. 2012. Financial early warning system model and data mining application for risk detection. Expert Systems with Applications, 39 (6), 6238-6253. DOI: 10.1016/j.eswa.2011.12.021

Kyong, J.O., Tae, Y.K, Chiho, K., Suk, J.L. 2006. Using neural networks to tune the fluctuation of daily financial condition indicator for financial crisis forecasting. Advances in Artificial Intelligence, 4304, 607-616. DOI: 10.1016/j.eswa.2011.12.021

Laitinen, E.K. 1992. Prediction of failure of a newly founded firm. Journal of Business, 7, 323-340. DOI: 10.1016/0883-9026(92)90005-C

Laitinen, E.K., Chong, H.G. 1999. Early warning system for crisis in SMEs: Preliminary evidence from Finland and the UK. Journal of Small Business and Enterprise Development, 6 (1), 89-102. https://www. researchgate.net/profile/H_Gin_Chong/publication/242337131_Early-warning_system_for_crisis_ in_SMEs_preliminary_evidence_from_Finland_ and the_UK/links/5520a0e10cf2a2d9e1434cbe.pdf

Lee, S.H., Urrutia, J.L. 1996. Analysis of insolvency prediction in the property liability insurance industry: A comparison of logit and hazard models. Journal of Risk and Insurance, 63, 121-130.

Lehmann, B. 2003. Is it worth the while? The relevance of qualitative information in credit rating, Working Paper presented at the EFMA 2003 Meetings, 
Helsinki, Finland, 25-29 June 2003, 1-25. http://papers.ssrn.com/sol3/papers.cfm?abstract_id $=410186$

Lestano, L., Jacobs, L.J. Kuper, G.H. 2004. Indicators of financial crises do work! An early warning system for six Asian countries. CCSO Working Paper 13. Department of Economics, University of Groningen, the Netherlands. http://econpapers.repec. org/paper/wpawuwpif/0409004.htm

Li, S., Wang, S. 2014. A financial early warning logit model and its efficiency verification approach. Knowledge-Based Systems, 70, 78-87. DOI: 10.1016/j.knosys.2014.03.017

Liang, D., Lu, C.-C., Tsai, C.-F., Shih, G.-A. 2016. Financial ratios and corporate governance indicators in bankruptcy prediction: A comprehensive study. European Journal of Operational Research, 252 (2), 561-572. DOI: 10.1016/j.ejor.2016.01.012

Lin, W.-Y., Hu, Y.-H., Tsai, C.-F. 2012. Machine learning in financial crisis prediction: A survey IEEE Transactions on Systems, Man and Cybernetics - Part C: Applications and Reviews, 42 (4), 421-436. 10.1109/ TSMCC.2011.2170420

Lin, F.-Y., Liang, D., Chu, W.-S. 2010. The role of nonfinancial features related to corporate governance in business crisis prediction. Journal of Marine Science and Technology, 18 (4), 504-513. http://citeseerx.ist.psu.edu/viewdoc/download?doi=10.1.1.463.9 $163 \&$ rep $=$ rep1\&type $=$ pdf

Lussier, R.N. 1995. A nonfinancial business success versus failure prediction model for young firms. Journal of Small Business Management, 33 (1), 8-20. http://search.proquest.com/openvi ew/88a9dbbdad41d0e9af99d92b78fbb1d6/1?pqorigsite $=$ gscholar

Lussier, R.N., Corman, J. 1994. A success vs. failure prediction model of the manufacturing industry, Paper presented at the Conference of the Small Business Institute Director's Association, San Antonio, Texas, February 1994, 48, 1-5.

Maltz, A.C., Shenhar, A.J., Reilly, R.R. 2003. Beyond the balanced scorecard: refining the search for organizational success measures. Long Range Planning, 36, 187-204. DOI: 10.1016/S0024-6301(02)00165-6

Mączyńska, E. 1994. Ocena kondycji przedsiębiorstwa. Uproszczone metody. Życie Gospodarcze, 38, 42-45. http://bazekon.icm.edu.pl/bazekon/element/ bwmeta1.element.ekon-element-000000100966
Mączyńska, E., Zawadzki, M. 2006. Dyskryminacyjne modele predykcji upadłości przedsiębiorstw. Ekonomista, 2, 205-217. http://www.pte.pl/pliki/2/12/ Ekonomista\%2025\%2002\%2006ostfragment.pdf

Mensah, Y.M. 1984. An examination of the stationarity of multivariate bankruptcy prediction models: a methodological study. Journal of Accounting Research, 22 (1), 380-395. https://www.researchgate.net/profile/Yaw_Mensah/publication/259673939_An_Examination_of_the_Stationarity_of_Multivariate_ Bankruptcy_Prediction_Models_A_Methodological_Study/links/570b167908ae2eb9422004a7.pdf

Nehrebecka, N., Dzik, A.M. 2012. Konstrukcja miernika szans na bankructwo firmy. Narodowy Bank Polski. Departament Edukacji i Wydawnictw. http://lodz.stat.gov.pl/gfx/lodz/userfiles/_public/ pliki/inne/201311_d_konf_swr_nehrebecka.pdf

Noga, T., Adamowicz, K., Jakubowski, J. 2014. Discriminating methods in the assessment of financial situation in timber industry enterprises. Acta Sci. Pol., Silv. Colendar. Rat. Ind. Lignar., 13 (1), 25-35. http://www.forestry.actapol.net/pub/3_1_2014.pdf

Ohlson, J. 1980. Financial Ratios and the Probabilistic Prediction of Bankruptcy. Journal of Accounting Research, 18 (1), 109-131. DOI: 10.2307/2490395

Ooghe, H., Camerlynck, J., Balcaen, S. 2003. The Ooghe-Joos-De Vos failure prediction models: a cross-industry validation. Brussels Economic Review, 46 (1), 39-70.

Ozgulbas, N., Koyuncugil, A.S. 2010. Financial early warning system for risk detection and prevention from financial crisis. In: Surveillance Technologies and Early Warning Systems: Data Mining Applications for Risk Detection (eds.: A.S. Koyuncugil, N. Ozgulbas). Idea Group Inc., New York, 76-108.

Pantalone, C., Platt, M. 1987. Predicting failures of savings and loan associations. Areuea Journal, 15, $46-64$.

Platt, H., Platt, M. 2002. Predicting Corporate Financial Distress: Reflections on Choice-Based Sample Bias. Journal of Economics and Finance, 2. DOI: 10.1007/BF02755985

Prusak, B. 2004. Metody wykorzystywane w analizie porównawczej modeli oceny zagrożenia przedsiębiorstw upadłością. Wydział Zarządzania i Ekonomiki Politechniki Gdańskiej, 1-5. http:// wwwl.zie.pg.gda.pl/ pb/ap.pdf 
Prusak, B. 2012. Zalety i ograniczenia modeli prognozowania zagrożenia przedsiębiorstw upadłością. Wyd. Oficyna wydawnicza SGH, Warszawa.

Salas, V., Saurina, J. 2002. Credit risk in two institutional regimes: Spanish commercial and savings banks. Journal of Financial Services Research, 22 (3), 203-224. DOI:10.1023/A:1019781109676

Sheppard, J.P. 1994. Strategy and bankruptcy: An exploration into organizational death. Journal of Management, 20 (4), 795-833. http://www.sfu. ca/ sheppard/papers/JPS94c_old.pdf

Slowinski, R., Zopounidis, C. 1995. Application of the Rough Set Approach to Evaluation of Bankruptcy Risk. Int. J. Intell. Syst. Acc. Fin. Mgmt., 4, 27-41. DOI: 10.1002/j.1099-1174.1995.tb00078.x

Stanisz, A. 2007. Przystępny kurs statystyki z zastosowaniem STATISTICA PL na przykładach $z$ medycyny (3). Analizy wielowymiarowe. StatSoft Polska, Kraków.

Taffler, R.J. 1984. Empirical models for the monitoring of UK corporations. Journal of Banking and Finance, 8, 199-227. DOI: 10.1016/03784266(84)90004-9

Taffler, R.J., Tisshaw, H. 1977. Going, going, gone-four factors which factors which predict. Accountancy, March, 50-54.

Trieschmann, J.S., Pinches, G.E. 1973. A multivariate model for predicting financially distressed property-liability insurers. Journal of Risk and Insurance, 40, 327-338. DOI:10.2307/252222

Tymoszczuk, M. 2013. Skuteczność modeli prognozowania upadłości przedsiębiorstw a upływ czasu-porównanie popularnych Polskich modeli wielowymiarowej analizy dyskryminacyjnej $\mathrm{z}$ modelem zbudowanym przez autorkę. In: Upadłości, bankructwa i naprawa przedsiębiorstw - Wybrane zagadnienia (eds.: A. Adamska., E. Mączyńska). SGH, 12, 193-194.

Wardzińska, K. 2012. Przykład zastosowania analizy dyskryminacyjnej do oceny sytuacji finansowej przedsiębiorstw. Ekonomia i Zarzq̨dzanie, 4 (3),
197-208. http://zneiz.pb.edu.pl/data/magazine/article/118/3.4_wardzinska.pdf

Wędzki, D. 2005. Wielowymiarowa analiza bankructwa na przykładzie budownictwa. Badania Operacyjne i Decyzyjne, 2, 59-81.

Wierzba, D. 2000. Wczesne wykrywanie przedsiębiorstw zagrożonych upadłością na podstawie analizy wskaźników finansowych - teoria i badania empiryczne. Zeszyty Naukowe Wyższej Szkoty Ekonomiczno-Informatycznej w Warszawie, 9, 79-105.

Wojnar, J. 2014. Ocena skuteczności modeli analizy dyskryminacyjnej do prognozowania zagrożenia finansowego spółek giełdowych. Zeszyty Naukowe Małopolskiej Wyższej Szkoty Ekonomicznej w Tarnowie, 1 (24), 221-231. http://zn.mwse.edu.pl/wojnar-jolanta-ocena-skutecznosci-modeli-analizydyskryminacyjnej-do-prognozowania-zagrozeniafinansowego-spolek-gieldowych/

Wu, J.L. 2007. Do Corporate Governance Factors Matter for Financial Distress Prediction of Firms? Evidence from Taiwan (Doctoral dissertation, University of Nottingham).

Xu, K., Zhao, Q., Bao, X. 2015. Study on early warning of enterprise financial distress - based on partial leastsquares logistic regression. Acta Oeconomica, 65, 3-16. DOI: http://dx.doi.org/10.1556/032.65.2015. S2.2

Yang, B., Ling, X.L., Hai, J., Jing, X. 2001. An early warning system for loan risk assessment using artificial neural networks. Knowledge Based Systems, 14 (5/6), 303-306. DOI: 10.1016/S09507051(01)00110-1

Zavgren, C. 1985. Assessing the vulnerability to failure of American industrial firms: A logistics analysis. Journal of Accounting Research, 22, 59-82. DOI: 10.1111/j.1468-5957.1985.tb00077.x

Zmijewski, M.E. 1984. Methodological issues related to the estimation of financial distress prediction models. Journal of Accounting Research, Supplement, 59. 